MARY HALL-CRAGGS ET $A L .:$ HOMOZYGOUS SICKLE-CELL ANAEMIA

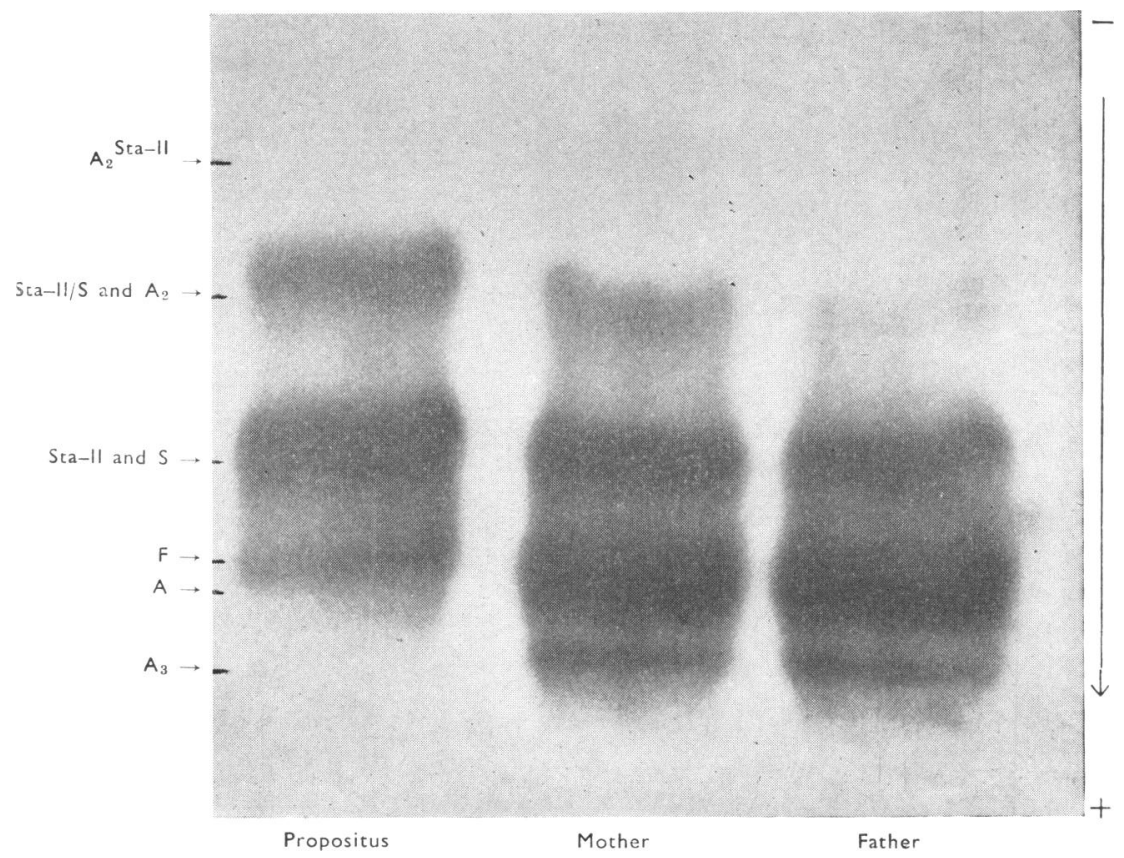

Fig. 1.-Left: propositus. Middle : mother of propositus. Right: father. Starch-gel electrophoresis of haemoglobin with 'discontinuous buffer system of Poulik (1957). By this method $\mathrm{Hb} S$ and $\mathrm{Hb}$ Sta-II, and $\mathrm{Hb}$ Sta-II/S and $\mathrm{Hb}$

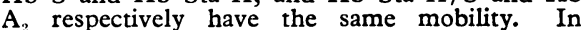
order from the negative pole one sees:- Pro-

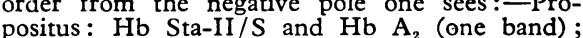
positus: $\mathrm{Hb}$ Sta-II/S and $\mathrm{Hb} \mathrm{A}_{2}$ (one band); $\mathrm{Hb} \mathrm{S}$; $\mathrm{Hb}$ F. Mother: $\mathrm{Hb} \mathrm{A}_{2} \mathrm{Sta}-\mathrm{II}$ (trace), $\mathrm{Hb} \mathrm{Sta}-\mathrm{II}$ and $\mathrm{Hb} \mathrm{A}_{2}$ (one band), $\mathrm{Hb}$ a

Father: $\mathrm{Hb} \mathrm{A}_{2}, \mathrm{Hb} \mathrm{S}, \mathrm{Hb} \mathbf{A}$, and $\mathrm{Hb} \mathrm{A}$.

Fig. 2.-Hbs $A+S t a-I I$ (left) and $A+S+L$ (right) Chromatography with IRC-50 at $\mathrm{pH} 6$ (Huisman and Prins, 1955). The slow-moving non-sickling $\mathrm{Hb} \mathrm{Sta}-\mathrm{II}$ moves by this method behind $\mathrm{Hb} \mathrm{S}$ and faster than $\mathrm{Hb} \mathrm{L}$.

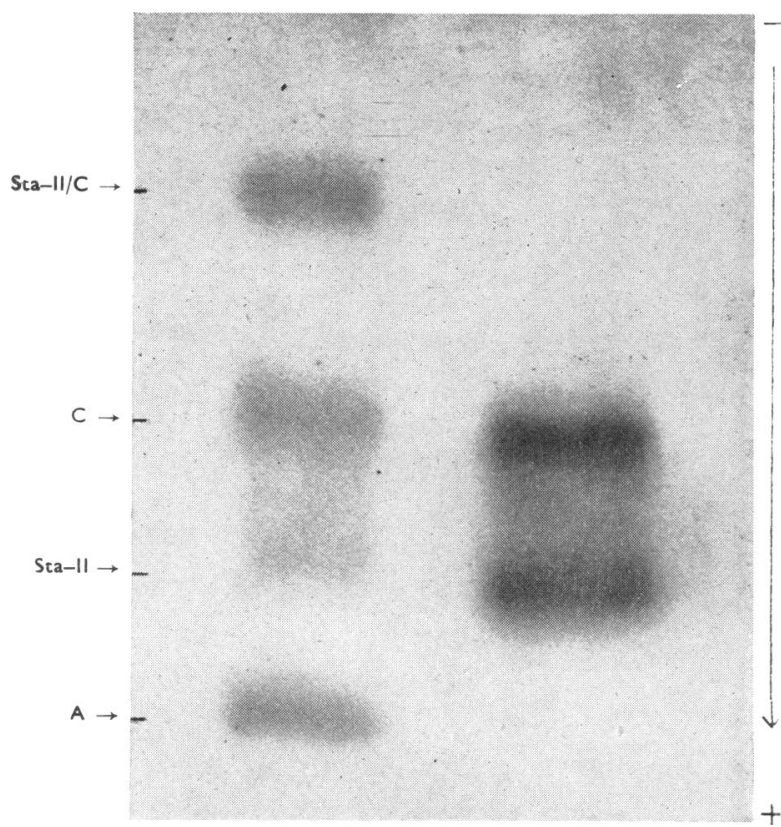

FIG. 3.- "Hybridization" of $\mathrm{Hb} \mathrm{C}$ and $\mathrm{Hb}$ Sta-II. Methoc essentially the same as that used by Raper et al. (1960), bu isolation of pure haemoglobin according to De Vries, Joshua Lehmann, Hill, and Fellows (1963). Discontinuous starch ge electrophoresis of Poulik (1957) allowed to run for 12 hours at $+4^{\circ}$. Right: $\mathrm{Hb} \mathrm{C}$ and $\mathrm{Hb}$ Sta, untreated. Left : Botb Hbs after dissociation and reassociation.

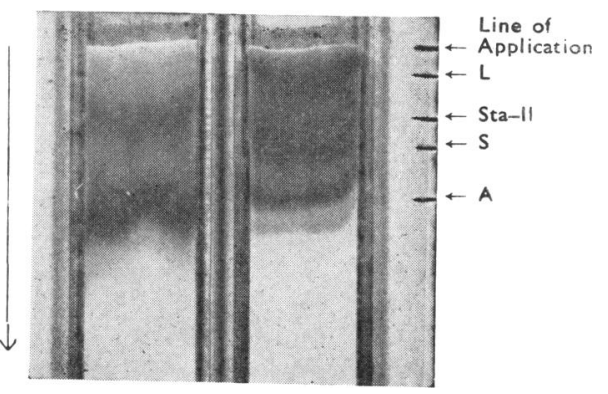

Fig. 4.-Demonstration of $\mathrm{Hb}$ A Sta-II. Starch-gel electrophoresis according to Poulik (1957). Left: Normal control showing $\mathrm{Hb} \mathrm{A}$ and $\mathrm{Hb} \mathrm{A}_{2}$. Right Hb A, Hb Sta-II, Hb A, and $\mathrm{Hb} \mathrm{A}_{2}$ sta-II. 
REFERENCES

Bernheim, M. (1956). Ann. Pédiat., 187, 153.

Cavanagh, J. B. (1962). Little Club Clinics in Developmental Medicine, No. 6, p. 49.

Duffy, P. E., Portnoy, B., Mauro, J., and Wehrle, P. F. (1957). Neurology (Minneap.), 7, 664.

Ford, F. R., and Schaffer, A. J. (1927). Arch. Neurol. Psychiat. (Chic.), 18, 323 .

Gastaut, H., Vigoroux, M., Trevisan, C., and Regis, H. (1957). Rev. neurol., 97, 37.

Goldstein, S. L., and Burgess, J. P. (1958). Amer. f. Dis. Child., 95, 538 .
Gunning, A. J., Pickering, G. W., Robb-Smith, A. H. T., and Ross Russell, R.' (1964). Quart. F. Med., 33, 155.

Klotz (1911). Quoted by Ford and Schaffer (1927).

Mitchell, R. G. (1952). Arch. Dis. Childh., 27, 95.

Norman, R. M. (1953). Proc. roy. Soc. Med., 46, 627

- (1962). Little Club Clinics in Developmental Medicine, No. 6, p. 37.

Sandifer, P. (1962). Ibid, No. 6, p. 17

Shillito, J. (1964). F. Neurol. Neurosurg. Psychiat., 26, 559.

Shillito, J. (1964). ₹. Neurol. Neurosurg. Psychiat.,

Strümpell, A. (1884). Dtsch. med. W schr., 10, 714.

Till, K., and Hoare, R. D. (1962). Little Club Clinics in Developmental Medicine, No. 6, p. 69.

\title{
Homozygous Sickle-cell Anaemia Arising from Two Different Haemoglobins $S$
}

\author{
Interaction of Haemoglobins S and Stanleyville-II
}

\author{
MARY HALL-CRAGGS,* M.B., B.S. ; P. D. MARSDEN,* M.B., M.R.C.P., M.R.C.P.ED. ; \\ A. B. RAPER, $\dagger$ M.D., M.R.C.P. ; H. LEHMANN, $\ddagger$ M.D., SC.D., F.R.C.P. ; D. BEALE, $\ddagger$ B.SC.
}

[With Special Plate]

Brit. med. F., 1964, 2, 87-89

It is established that human adult haemoglobin ( $\mathrm{Hb} \mathrm{A}$ ) consists of $\alpha$ and $\beta$ polypeptide chains, and that each individual inherits genes determining the nature of these chains from both parents. There exist numerous variants of each type of chain, resulting in a large variety of mutants of $\mathrm{Hb} \mathrm{A}$. Many of them are rare and have a limited geographical distribution, and thus, although many combinations of abnormal haemoglobins are possible, only a few have been found, and combinations involving one abnormal $\alpha$-chain and one abnormal $\beta$-chain are particularly rare. It is these latter combinations (Smith and Torbert, 1958 ; Atwater, Schwartz, and Tocantins, 1960 ; Raper, Gammack, Huehns, and Shooter, 1960 ; Baglioni and Ingram, 1961; McCurdy, Pearson, and Gerald, 1961; Weatherall, Sigler, and Baglioni, 1962) that throw the greatest light on the genetics of haemoglobin production, and are the best evidence for the validity of the current genetic theory. There exist in the region of the Upper Nile at least three haemoglobin variants: sickle-cell haemoglobin ( $\mathrm{Hb} \mathrm{S}$ ), which is common (Lehmann and Raper, 1949), and Hbs Stanleyville-I and -II (Sta-I and Sta-II) (Dherte, Vandepitte, Ager, and Lehmann, 1959), which are rare. This report deals with a family in which the genes for both $\mathrm{Hb} S$ and $\mathrm{Hb}$ Sta-II are segregating.

\section{Case History}

The propositus was a male child of parents belonging to the Ulur tribe from the West Nile region of Uganda. He was first seen in 1961 at the age of 1 year, and until the age of 21 years he regularly attended the sickle-cell anaemia clinic at Mulago Hospital, Kampala. During this period he presented all the features of classical sickle-cell anaemia; a haemolytic crisis occurred during the first week of observation, and during the next four months he suffered from typical sicklaemic "dactylitis" of the hands and feet on several occasions; he also

\footnotetext{
* Sickle-cell Anaemia Clinic, Mulago Hospital, Kampala, Uganda. † Royal Infirmary, Bristol.

$¥$ M.R.C. Abnormal Haemoglobin Research Unit, University Department of Biochemistry, and Addenbrooke's Hospital, Cambridge.
}

had splenomegaly and occasional jaundice. The haemoglobin level ranged from 4.1 to $10 \mathrm{~g} . / 100 \mathrm{ml}$. and the reticulocyte count from 3 to $40 \%$. The appearance of the blood films was regarded as that of sickle-cell anaemia, and on electrophoretic analysis of the haemolysate only $\mathrm{Hbs} \mathrm{S}$ and $\mathrm{F}$ were noted.

In 1963 , at the age of 3 years, the child was examined again. On this occasion his blood contained $10 \% \mathrm{Hb} \mathrm{F}$, but on electrophoresis his haemoglobin was noticed to consist of three components- $\mathrm{Hb} \mathrm{F}, \mathrm{Hb} \mathrm{S}$, and a third band of slow mobility occupying approximately the position of $\mathrm{Hb} \mathrm{E}$. It was clear that the child could not be a classical sickle-cell homozygote, although he still presented the clinical and haematological picture of sickle-cell anaemia.

Fortunately the parents were available for examination on this occasion. Neither of them were anaemic, and their blood films were normal. Both exhibited sickling, and the father's haemoglobin showed the characteristic pattern on electrophoresis of the sickle-cell trait. The mother's haemoglobin, however, separated on electrophoresis into three bands, in the respective positions of $\mathrm{Hb} \mathrm{A}, \mathrm{Hb} \mathrm{S}$, and the same slow component that the child had shown. The middle band, in the $\mathrm{Hb} S$ position, was more prominent than the other two (Special Plate, Fig. 1).

\section{Family History}

On examination of the results from the mother it was possible to suggest that she had inherited two abnormal haemoglobin genes: one for $\mathrm{Hb} \mathrm{S}$ (a $\beta$-chain variant) and the other for an $\alpha$-chain variant of the same mobility-perhaps, for example, $\mathrm{Hb} \mathrm{D}_{\alpha}$. These two would occupy the same position electrophoretically, accounting for the prominent middle band observed. A person of this genetic constitution would, moreover, also form $\mathrm{Hb} \mathrm{A}$ and a hybrid haemoglobin molecule containing both the abnormal $\alpha_{2}$ and $\beta_{2}$ sub-units; and thus the three components observed could be accounted for.

To confirm this hypothesis it was necessary to examine more members of the family, and one of us was able to assemble 20 
related persons at a remote place in the West Nile region. In addition, the younger brother of the propositus was available.

Among these 21 persons there were five different haemoglobin phenotypes. Three showed $\mathrm{Hb} \mathrm{A}$ only, though only one was a blood relation of the propositus. Nine showed two haemoglobin bands in the electrophoretic position of $\mathrm{Hbs} \mathrm{A}$ and $\mathrm{S}$ respectively, but of these only four showed the sickling phenomenon. Eight persons, all of whom showed sickling, produced the same triple haemoglobin pattern as had been seen in the mother of the propositus. One child, the younger brother of the propositus, possessed $\mathrm{Hbs} S$ and $\mathrm{F}$ only, and blood films confirmed that he suffered from sickle-cell anaemia. It was apparent that $\mathrm{Hb} \mathrm{S}$ and the abnormal haemoglobin were segregating separately.

\section{Identification of Non-sickling Abnormal Haemoglobin}

The haemolysates of those members showing the pattern $A+S$ without the sickling phenomenon were submitted to the following tests:

(a) Itano's (1953) Solubility Test.-In all of these subjects $50 \mathrm{mg}$. of haemoglobin was fully soluble in $2.24 \mathrm{M}$ phosphate buffer; this excludes the presence of $\mathrm{Hb} S$ and confirms the negative sickling tests.

(b) Electrophoresis on paper, starch gel, and cellulose acetate, using barbiturate and tris buffers of various $p H$, showed that the abnormal component had the mobility of $\mathrm{Hb} S$. But on resin chromatography at $p \mathrm{H} 6$, the abnormal fraction moved behind $\mathrm{Hbs} \mathrm{S}$ or $\mathrm{D}$, but further than $\mathrm{Hb} \mathrm{L}$ (Special Plate, Fig. 2). These are the properties of $\mathrm{Hb}$ Sta-II, previously found in two unrelated families in the part of the Congo bordering on the region of the Upper Nile (Dherte et al., 1959). This haemoglobin was known to be abnormal in the "core," the part of the haemoglobin molecule which remains insoluble after tryptic digestion (personal communication by Dr. C. Baglioni).

(c) Identification of the Mutant Chain.-The abnormal fraction was separated from $\mathrm{Hb} \mathrm{A}$ by paper electrophoresis, eluted, and concentrated. It was then submitted to hybridization experiments, first with canine haemoglobin following Itano and Robinson (1959), but using the starch-gel method of Huehns, Shooter, and Beaven (1962). In this type of hybridization experiment two characteristic hybrid haemoglobins are formed, one of canine $\alpha$ - and human $\beta$-chains, and one of human $\alpha$ - and canine $\beta$-chains. With our specimen, the canine $\alpha$-/human $\beta$-chain hybrid appeared in the expected position on starch-gel electrophoresis. But the human $\alpha-/$ canine $\beta$-chain hybrid was different from that obtained from normal $\mathrm{Hb} \mathrm{A}$. This indicated that the abnormality of the present specimen of $\mathrm{Hb}$ Sta-II resided in the $\alpha$-chain. Secondly, the abnormal variant was hybridized with pure human $\mathrm{Hb} \mathrm{C}$, a $\beta$-chain variant. The reaction expected in this case can be expressed as follows:

$$
\begin{aligned}
& a_{2} \mathrm{Sta}-\mathrm{II} \beta_{2} \mathrm{~A}+a_{2} \mathrm{~A} \beta_{2} \mathrm{C} \rightarrow a_{2} \mathrm{~A} \beta_{2} \mathrm{~A}+a_{2} \mathrm{~A} \beta_{2} \mathrm{C}+a_{2} \mathrm{Sta}-\mathrm{II} \beta_{2} \mathrm{~A}+a_{0} \mathrm{Sta}-\mathrm{II} \beta_{2} \mathrm{C} \\
& \mathrm{HbA} \quad \mathrm{HbC} \mathrm{Hb} \text { Sta-II Hb (Sta-II/C) }
\end{aligned}
$$

Two haemoglobin species, $\mathrm{Hb} \mathrm{A}$ and $\mathrm{Hb}$ (Sta-II/C), not present in the original reactants, should be produced ; and these were in fact observed (Special Plate, Fig. 3), confirming the location of the $\mathrm{Hb} \mathrm{Sta}-\mathrm{II}$ anomaly in the $\alpha$-chain. In a person with both normal and abnormal $\alpha$-chains, not only a variant of $\mathrm{Hb} \mathrm{A}$ should be found but, in addition, a variant of the minor component, $\mathrm{Hb} \mathrm{A} \mathrm{A}_{2}\left(\alpha_{2} \delta_{2}\right)$ should arise. In the present case the abnormal $\mathrm{Hb} \mathrm{A}_{2}$, of the composition $\alpha_{2}^{\text {Sta-II }} \delta_{2}$ would be expected to appear electrophoretically as a band as far behind normal $\mathrm{Hb} \mathrm{A}_{2}$ as $\mathrm{Hb}$ Sta-II lies behind $\mathrm{Hb} \mathrm{A}$. This additional band was in fact observed (Special Plate, Fig. 4).

(d) Peptide Analysis.-Isolated $\mathrm{Hb} \mathrm{Sta}-\mathrm{II}$ was submitted to tryptic digestion, and the resulting peptides were separated by electrophoresis and chromatography (the "finger-printing" technique) using Baglioni's (1961) modifications of Ingram's
(1958 technique. All the peptides that result from digestion of normal $\mathrm{Hb} \mathrm{A}$ were found in our specimen, but an additional soluble peptide was present (Fig. I). After tryptic digestion of normal $\mathrm{Hb} \mathrm{A}$, a "core" of insoluble peptides (amino-acid residues 93-139) always remains. We explain our finding by supposing that in $\mathrm{Hb}$ Sta-II one of the "core" peptides

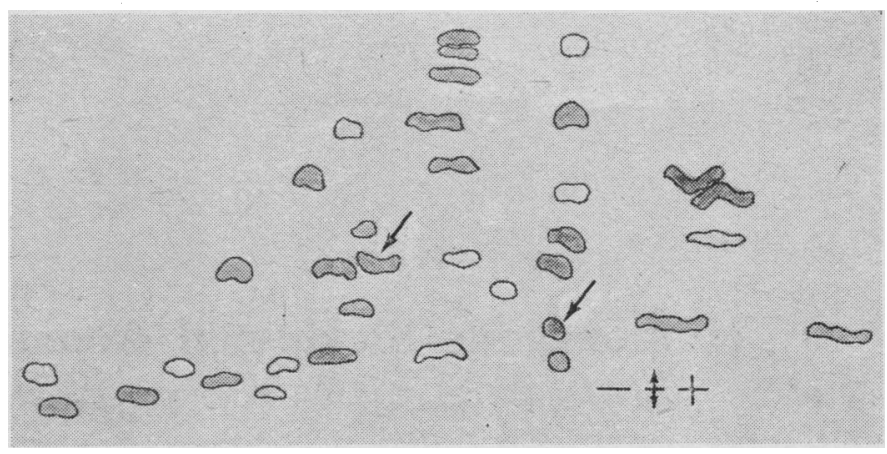

Fig. I.- " Fingerprint" of $\mathrm{Hb}$ Sta-II. All the soluble peptides of $\mathrm{Hb} \mathrm{A}$ are present. The right arrow indicates $\beta$-tryptic-peptide-I, which represents the first eight amino-acid residues of the $\beta$-chain, and which is left arrow indicates an additional soluble peptide. As the abnormality left arrow indicates an additional soluble peptide. As the abnormality
in $\mathrm{Hb}$ Sta-II rests in the $\alpha$-chain, this peptide must come from the usually insoluble "core" of the $\alpha$-chain.

differed from the normal in that it was susceptible to tryptic digestion, so that an additional soluble peptide was liberated. This confirmed an observation of Dr. C. Baglioni, who also had observed an additional peptide on "finger-printing" Hb Sta-II.

\section{Genotype and Phenotype of the Propositus}

Our identification of the genotypes of the parents of the propositus is as follows. The father's gene constitution is $\alpha^{\mathbf{A}} \alpha^{\mathbf{A}} / \beta^{\mathbf{A}} \beta^{\mathbf{S}}$, and the mother's $\alpha^{\mathbf{A}} \alpha^{\text {Sta-II }} / \beta^{\mathbf{A}} \beta^{\mathbf{S}}$. From such a

\begin{tabular}{|c|c|c|}
\hline Genotype & Phenotype & Haemoglobins \\
\hline$\alpha^{\mathrm{A}} \alpha^{\mathrm{A}} / \beta^{\mathrm{A}} \beta \mathrm{A}$ & $a_{2} \mathrm{~A} \beta_{2} \mathrm{~A}$ & $\mathrm{Hb} \mathrm{A}$ \\
\hline$\alpha^{\mathbf{A}} \alpha_{\alpha} \mathbf{A} / \beta \mathbf{A} \beta \mathbf{S}$ & $\alpha_{2} \mathrm{~A} \beta_{2} \mathrm{~A}, \alpha_{2} \mathrm{~A} \beta_{2} \mathrm{~S}$ & $\mathrm{Hb} \mathrm{A}+\mathrm{S}$ \\
\hline$\alpha^{\mathbf{A}} \alpha / \mathbf{A} \beta \mathbf{S} \beta \mathbf{S}$ & $a_{2} \mathrm{~A} \beta \mathrm{S}_{2}$ & $\mathrm{Hb} \mathrm{S}$ \\
\hline$\alpha^{A} \mathrm{~A}_{a} \mathrm{Sta}-\mathrm{II} / \beta^{\mathrm{A}} \beta \mathrm{A}$ & $a_{2}$ Sta-II $\beta_{2} \mathrm{~A}, \alpha_{2} \mathrm{~A} \beta_{2} \mathrm{~A}$ & $\mathrm{Hb} \mathrm{A}+\mathrm{Sta}-\mathrm{II}$ \\
\hline$\alpha^{A} A_{a} S \operatorname{Sta}-\mathrm{II} / \beta \mathrm{A} \beta \mathrm{S}$ & $\begin{array}{c}a_{2} \text { Sta-II } \beta_{2} \mathrm{~A}, a_{2} \text { Sta-II } \beta_{2} \mathrm{~S}, \\
a_{2} \mathrm{~A} \beta_{2} \mathrm{~A}, a_{2} \mathrm{~A} \beta_{2} \mathrm{~S}\end{array}$ & $\begin{aligned} & \text { Hb Sta-II } \\
+ & \mathrm{Hb}(\text { Sta-II/S) } \\
+ & \mathrm{Hb} \mathrm{A}+\mathrm{Hb} \mathrm{S}\end{aligned}$ \\
\hline$\alpha^{\mathbf{A}} \alpha \mathrm{Sta}-\mathrm{II} / \beta \mathbf{S} \beta \mathbf{S}$ & $a_{2} \beta A_{2} S, a_{2}$ Sta-II $\beta_{2} S$ & $\mathrm{Hb} \mathrm{S}+($ Sta-II $/ \mathbf{S})$ \\
\hline
\end{tabular}
mating the following offspring could result :

Among the siblings of the propositus, three of these six combinations were found- $\mathrm{Hb} \mathrm{A}+\mathrm{S}$ (III-14, III-15), Hb S (III-17), and $\mathrm{Hb} \mathrm{A}+\mathrm{S}+\mathrm{Sta}-\mathrm{II}+(\mathrm{Sta}-\mathrm{II} / \mathrm{S})(\mathrm{III}-13)$. In the rest of the family two others occurred- $\mathrm{Hb} \mathrm{A}$ and $\mathrm{Hb} \mathrm{A}+$ Sta-II. The propositus himself possessed $\mathrm{Hb} S$ and the slow component, and apparently was of genetic constitution $\alpha^{\mathbf{A}} \alpha^{\text {Sta-II }} / \beta^{\text {S }} \beta^{\text {s. If }}$. If the were so he could form no $\mathrm{Hb} A$. In fact, some haemoglobin was seen on electrophoresis on paper and starch in this child in a position that might be $\mathrm{Hb} \mathrm{A}+\mathrm{F}$, but he was known to possess $10 \%$ of $\mathrm{Hb} \mathrm{F}$, and on, electrophoresis in agar, where $\mathrm{Hbs} A$ and $F$ separate clearly, no $\mathrm{Hb}$ A was seen. Further, a "finger-print" of this child's haemoglobin demonstrated the absence of tryptic peptide $\beta \mathrm{TpI}$ of $\mathrm{Hb} \mathrm{A}$, indicating that all his $\beta$-chains were those of $\mathrm{Hb} \mathrm{S}$ and that $\mathrm{Hb} \mathrm{A}$ was absent (Fig. II).

The propositus therefore presents a new type of homozygous sickle-cell anaemia, one in which there is an added $\alpha$-chain 


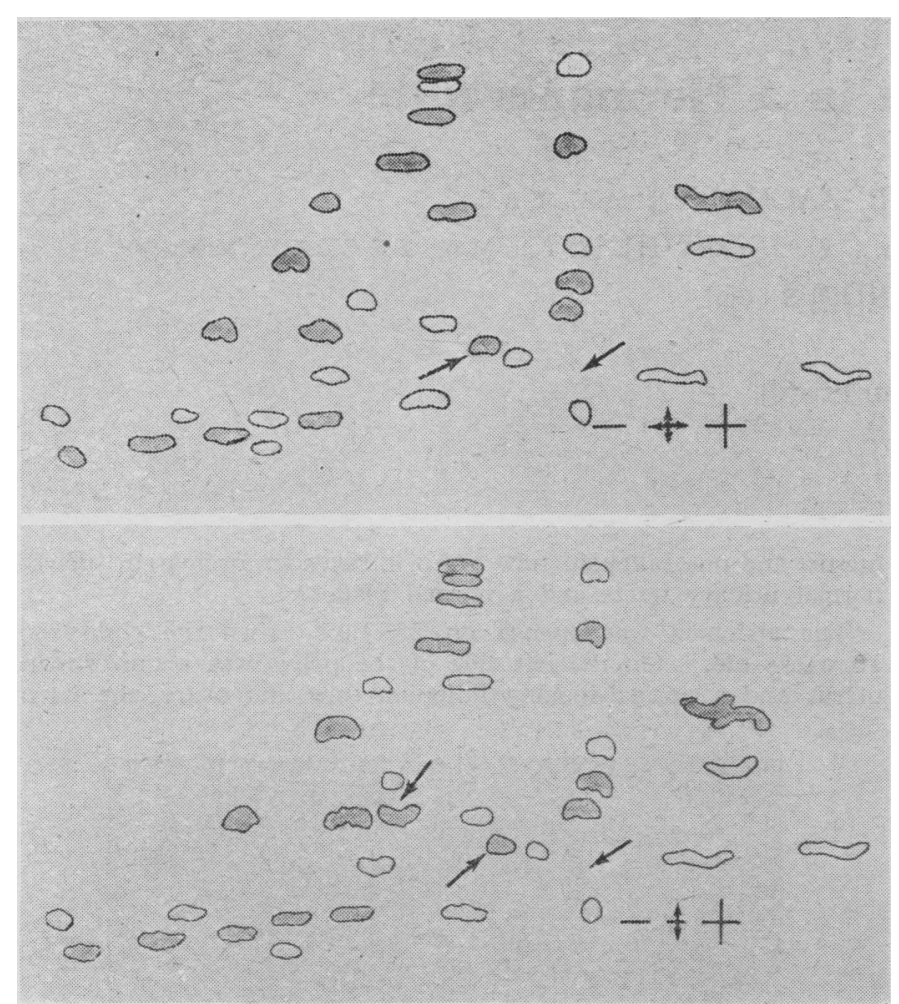

FIG. II.- "Fingerprints" of $\mathrm{Hb} S$ (top) and the haemoglobin of the propositus (bottom). In both $\beta$-tryptic-peptide-I is displaced from its position in $\mathrm{Hb} \mathrm{A}$ (right arrow) to that of the position of $\beta$-tryptic-peptideI of sickle-cell haemoglobin (second arrow from right). Hence the propositus does not possess the $\beta$-chain of $\mathrm{Hb} \mathrm{A}$. In the chromatogram of the propositus's haemoglobin the abnormal Sta-II peptide is also present (left arrow).

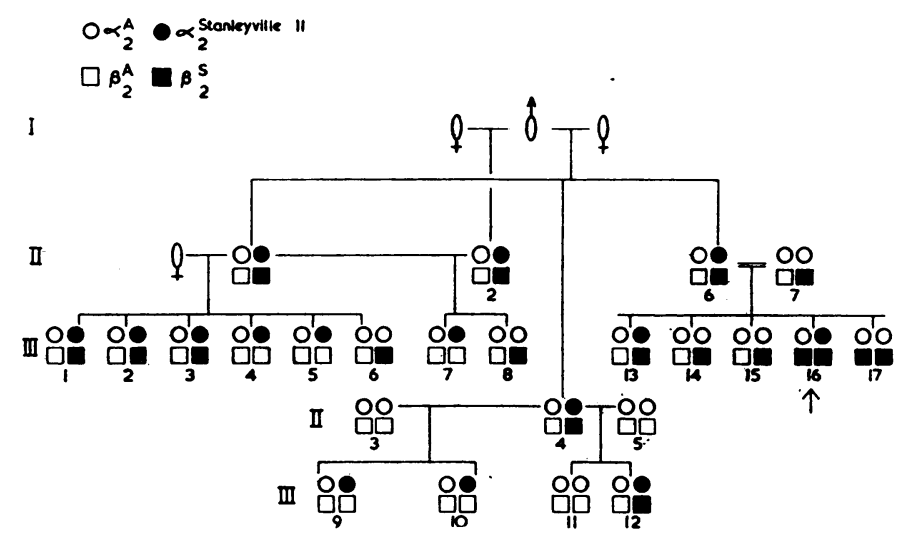

FIG. III.-Family tree showing respective distribution of polypeptide chains of Hbs A, S, and Sta-II. The propositus (III-16) has no $\beta^{\mathbf{A}}$ chain, and is homozygous for the gene responsible for the $\beta^{\mathrm{S}}$-chain. abnormality, so that his sickle-cell haemoglobin is in two forms-classical $\mathrm{Hb} \mathrm{S}$ and the new $\mathrm{Hb}$ (Sta-II/S). This combination, as might be expected, does not differ in its clinical effect from the only type of homozygous sickle-cell anaemia already known. Finally, the current theory that adult haemoglobin variants result from the combination of the various $\alpha_{2}-$ and $\beta_{2}$-sub-units, each the product of one of the inherited genes, is fully supported by the present family study. In the four third-generation sibships (III 7 to 17) (Fig. III) in which parental phenotypes were known, there was, on this theory, the possibility that nine haemoglobin genotypes should be represented ; in fact, among the 11 children concerned we found six of the possible combinations, and none that contradicted the theory.*

\section{Summary}

In a Nilotic family in Uganda it was found that there was independent segregation of $\mathrm{Hbs} \mathrm{A}, \mathrm{S}$, and Stanleyville-II (Sta-II).

The Hb Sta-II was identified as an $\alpha$-chain mutant with a mutation in the $\alpha$-chain in the region of amino-acid residues 93-139.

In the whole family six of the nine possible haemoglobin phenotypes were found: $\mathrm{Hb} \mathrm{A}, \mathrm{Hb} \mathrm{A}+\mathrm{S}, \mathrm{Hb} \mathrm{A}+\mathrm{Sta}-\mathrm{II}, \mathrm{Hb} \mathrm{S}$, $\mathrm{Hb} \mathrm{A}+\mathrm{S}+\mathrm{Sta}-\mathrm{II}+(\mathrm{Sta}-\mathrm{II} / \mathrm{S})$, and $\mathrm{Hb} \mathrm{S}+(\mathrm{Sta}-\mathrm{II} / \mathrm{S})$ (the propositus).

The propositus presents a new type of homozygous sicklecell anaemia.

'In the February number of Blood (1964, 23, 206), R. P. Pugh, Th. V.
Monical, and V. Minnich report the observation of a sickle-celi
anaemia with two adult haemoglobins, Hb S and $\mathrm{Hb}$ G Philadelphia/S.

\section{REFERENCES}

Atwater, J., Schwartz, I. R., and Tocantins, L. M. (1960). Blood, 15, 901. Baglioni, C. (1961). Biochim. biophys. Acta (Amst.), 48, 392 and Ingram, V. M. (1961). Nature (Lond.) 189, 465.

DeVries, A., Joshua, H., Lehmann, H., Hill, R. L., and Fellows, R E. (1963). Brit. F. Haemat., 9, 484.

Dherte, P., Vandepitte, J., Ager, J. A. M., and Lehmann, H. (1959). Brit. med. $7 ., 2,282$.

Huehns, E. R., Shooter, E. M., and Beaven, G. H. (1962). F. molec. Biol., 4, 323.

Huisman T. H. J and Prins, H. K. (1955), 7. Lab clin Med, 46, 255.

Ingram, V. M. (1958). Biochim. biophys. Acta (Amst.), 28, 539.

Itano, H. (1953). Arch. Biochem., 47, 148.

and Robinson, E. (1959). N Nature (Lond.), 184, 1468.

Lehmann, H., and Raper, A. B. (1949). Ibid., 164, 494.

McCurdy, P. R., Pearson, H., and Gerald, P. S. (1961). F. Lab. clin. Med., 58, 86.

Poulik, M. D. (1957). Nature (Lond.), 180, 1477.

Raper, A. B., Gammack, D. B., Huehns, E. R., and Shooter, E. M. (1960). Brit. med. ₹., $2,1257$.

Smith, E. W., and Torbert, J. V. (1958). Bull. Johns Hopk. Hosp., 102,

Weatherall, D. J., Sigler, A. T., and Baglioni, C. (1962). Ibid., 111, 143. 